\title{
Lowry-Wood syndrome
}

INSERM

\section{Source}

INSERM. (1999). Orphanet: an online rare disease and orphan drug data base. Lowry-

Wood syndrome. ORPHA:1824

Lowry-Wood syndrome is characterized by the association of epiphyseal dysplasia, short stature, microcephaly and, in the first reported cases, cong enital nystagmus. So far, less than 10 cases have been described in the literature. Variable degrees of intellectual deficit have also been reported. Other occasional features include retinitis pigmentosa (see this term) and coxa vara. Transmission appears to be autosomal recessive. 